American Journal of Biochemistry and Biotechnology 4 (4): 317-324, 2008

ISSN 1553-3468

(C) 2008 Science Publications

\title{
The Effect of Molecular Chaperone, Alpha-Crystallin, on the Heat-Induced Aggregation of Beta-lactoglobulin
}

\author{
Arezou Ghahghaei \\ Department of Biology, Faculty of Science, University of Sistan and Baluchestan, \\ Zahedan, Iran
}

\begin{abstract}
Aggregation of beta-lactoglobulin occurs mainly via intermolecular disulphide bond exchange. Upon heating, beta-lactoglobulin aggregated which increased with increasing $\mathrm{pH}$. The presence of DTT led to more rapid aggregation and precipitation of beta-lactoglobulin. AlphaCrystallin prevented the aggregation of heat-stressed beta-lactoglobulin and was a more efficient chaperone at higher $\mathrm{pH}$ values. In the presence of DTT, however, alpha-crystallin was a less efficient chaperone due to faster aggregation of heated and reduced beta-lactoglobulin.
\end{abstract}

Key words: Beta-lactoglobulin, alpha-crystallin, crowding agent

\section{INTRODUCTION}

Beta-lactoglobulin is a major whey protein of milk $^{[1-3]}$, which at physiological $\mathrm{pH}$ values exists as a $\operatorname{dimer}^{[4,5]}$. Each monomer has a molecular weight of $18.3 \mathrm{kDa}$, contains 162 amino acid residues, two disulphide bonds (C106-C119 and C66-C160) and one free cysteine residue $(\mathrm{C} 121)^{[6-8]}$. Upon heating, betalactoglobulin dissociates into monomers, leading to exposure of hydrophobic groups and the free sulfhydryl group $^{[9,10]}$. This then gives rise to aggregation and/or polymerization $^{[4,5,9,11,12]}$. Beta-lactoglobulin is sensitive to heating at $60-100^{\circ} \mathrm{C}$. During heating, the protein undergoes an initial dissociation of dimers followed by conformational changes which increase the exposure of previously buried hydrophobic groups and the thiol $\operatorname{group}^{[4,9,12,13,14]}$.

Alpha-Crystallin is the major protein component of the mammalian eye lens, making up $50 \%$ of its dry weight ${ }^{[15,16]}$. It belongs to the sHsp family ${ }^{[17]}$ and acts as a molecular chaperone ${ }^{[17,18]}$ by preventing aggregation of target proteins (e.g. beta and gama-crystallins) under stress conditions through the formation of stable, soluble high-molecular mass complexes ${ }^{[19,20]}$.

Aggregation of beta-lactoglobulin occurs mainly via intermolecular disulphide bond exchange, i.e. the aggregation is not (in the main) due to nucleationdependent processes ${ }^{[7,9]}$ but arises from polymerization. In a previous study ${ }^{[21]}$ indicated that alpha-crystallin did not inhibit the aggregation of a serpin (AT (antitrypsin)) which aggregated via a polymerization reaction but did inhibit a serpin aggregation (ACT (antichymotrypsin)) when occurring via a nucleation-dependent mechanism.
Therefore, in order to explore the effect of alphacrystallin on beta-lactoglobulin aggregation, a heating assay of beta-lactoglobulin at different $\mathrm{pH}$ values in the presence and absence of alpha-crystallin was performed.

\section{MATERIALS AND METHODS}

Chemicals and reagents: Alpha-Crystalline were prepared from bovine lenses obtained from a local abattoir. dithiothreitol (DTT), $\mathrm{NaN}_{3}$, Acrylamide, Glycine and beta-lactoglobulin were obtained from Sigma-Aldrich (St. Louis, U.S.A.).

Isolation and purification of alpha-, beta- and gamacrystallins from bovine eye lenses: The purification of alpha-crystallin was performed according to the method of Slingsby and Bateman ${ }^{[22]}$ using a Sephacryl S 300HR column with a diameter of $2.6 \mathrm{~cm}$ and length of $100 \mathrm{~cm}$ in $50 \mathrm{mM}$ Tris, $0.04 \% \mathrm{NaN}_{3}, \mathrm{pH} 7.5$ buffer and a flow rate of $20 \mathrm{~mL} \mathrm{~h}^{-1}$. The elution time of alpha-crystallin was approximately 8-10 h. The purity of the alphacrystallin fractions was checked by SDS-PAGE (not shown).

Heat stress assay: Beta-lactoglobulin (at a final concentration of $5 \mathrm{mg} \mathrm{mL}$ ) in $50 \mathrm{mM}$ sodium phosphate, $100 \mathrm{mM} \mathrm{NaCl}$ and $2.5 \mathrm{mM}$ EDTA, $0.05 \%$ (w/v) $\mathrm{NaN}_{3}$ was incubated at $70^{\circ} \mathrm{C}$ at different $\mathrm{pH}$ values $(6.5,7.0,7.5$ and 8.0) in the presence and absence of 1:1 w:w ratio of beta-lactoglobulin: alphacrystallin and/or in the absence and presence of DTT. Samples were prepared in $1 \mathrm{~cm}$ quartz cuvettes to a final volume of $1 \mathrm{~mL}$. To avoid evaporation from cuvettes, a Seal Plate strip was used made of plastic stable up to $120^{\circ} \mathrm{C}$. 
Aggregation of beta-lactoglobulin was monitored as light scattering at $360 \mathrm{~nm}$ over $3 \mathrm{~h}$ with data collected every 2 minutes using a Cary 500 Scan UVVIS- NIR spectrophotometer.

Protein characterization by sodium dodecyl sulphate polyacrylamide gel electrophoresis (SDS-PAGE): Sodium dodecyl sulphate polyacrylamide gel electrophoresis (SDS-PAGE) was used to assess the extent of aggregation of heated beta-lactoglobulin in the presence and absence of alpha-crystallin at different $\mathrm{pH}$ values.

About $100 \mu \mathrm{L}$ of heated beta-lactoglobulin solution was taken and pellets were removed by centrifugation. Proteins were dissolved in $25 \mu \mathrm{L}$ of phosphate buffer and $25 \mu \mathrm{L}$ of non-reduced loading dye buffer. To obtain information on heated beta-lactoglobulin, which was not aggregated, $25 \mu \mathrm{L}$ of supernatant of heated sample were taken and then $25 \mu \mathrm{L}$ of reduced buffer were added to supernatant sample.

Samples were boiled and then loaded on to $15 \%$ $(\mathrm{v} / \mathrm{v})$ polyacrylamide resolving and $4 \%(\mathrm{v} / \mathrm{v})$ stacking gel for separation. A Bio-Rad MiniProtein II or III apparatus with a Bio-Rad 1000/ 500 power supply were used to electrophorese the gels. Proteins were separated at $140-160 \mathrm{~V}$ for $1-1.5 \mathrm{~h}$ using SDS-PAGE running buffer $(0.1 \mathrm{M}$ Tris base, $0.1 \mathrm{M}$ glycine, $0.5 \%(\mathrm{w} / \mathrm{v})$ (SDS). Gels were stained overnight by shaking in Coomassie R Brilliant Blue. The gel background was destained in $10 \%(\mathrm{v} / \mathrm{v})$ acetic acid. Prior to imaging, gels were replaced into a final destain solution which contained $4 \%(\mathrm{v} / \mathrm{v})$ glycerol for $30 \mathrm{~min}$ to prevent cracking upon drying. Gels were imaged using a Canon $9950 \mathrm{f}$ image scanner.

\section{RESULTS}

The effect of $\mathrm{pH}$ on the aggregation of betalactoglobulin: It has been reported previously that increasing $\mathrm{pH}$ increases the rate of aggregation and precipitation of heated beta-lactoglobulin ${ }^{[9,23]}$. Accordingly, the effect of $\mathrm{pH}$ on the rate of aggregation and precipitation of beta-lactoglobulin was studied by heating the sample at $70^{\circ} \mathrm{C}$ and at different $\mathrm{pH}$ values between 6.5 and 8.0. As $\mathrm{pH}$ increased, the rate of aggregation of beta-lactoglobulin also increased (Fig. 1, Table 1).

The chaperone action of alpha-crystallin in preventing aggregation of heated beta-lactoglobulin at different $\mathrm{pH}$ values.

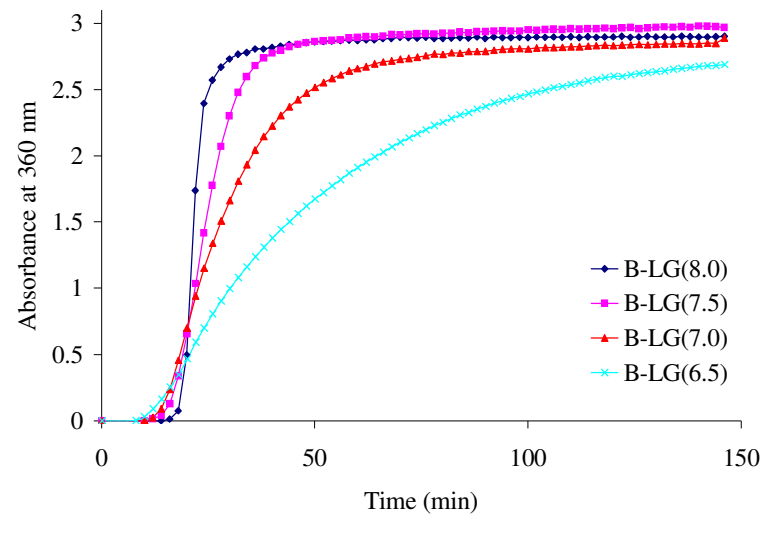

Fig. 1: Heat induced aggregation of beta-lactoglobulin at $5 \mathrm{mg} \mathrm{mL}^{-1}$ and different $\mathrm{pH}$ values. Protein was in total volume of $1 \mathrm{ml}$ of $50 \mathrm{mM}$ phosphate buffer, $0.05 \% \mathrm{NaN}_{3}, 100 \mathrm{mM} \mathrm{NaCl}$ and $2.5 \mathrm{mM}$ EDTA and the incubation temperature was $70^{\circ} \mathrm{C}$

Table 1: Summary of rate constants for aggregation of heat-stressed beta-lactoglobulin at different $\mathrm{pH}$ values. The standard deviation obtained from Sigmaplot upon regeneration calculation

\begin{tabular}{ll}
\hline$\beta$-lactoglobulin & Rate constants $\times 10^{-1}\left(\mathrm{~min}^{-1}\right)$ \\
\hline $\mathrm{pH}(8.0)$ & $4.37 \pm 0.45$ \\
$\mathrm{pH}(7.5)$ & $1.20 \pm 0.17$ \\
$\mathrm{pH}(7.0)$ & $0.99 \pm 0.34$ \\
$\mathrm{pH}(6.5)$ & $0.47 \pm 0.09$ \\
\hline
\end{tabular}

The chaperone-like action of alpha-crystallin in preventing the aggregation of beta-lactoglobulin was examined at different $\mathrm{pH}$ values. As shown in Fig. 2, alpha-crystallin is able to prevent the aggregation of beta-lactoglobulin at all $\mathrm{pH}$ values tested (i.e., 6.5, 7.0, 7.5 and 8.0). The efficiency of Alpha-crystallin as a molecular chaperone increased with increasing $\mathrm{pH}$ as demonstrated by its greater protection of betalactoglobulin against aggregation. At $\mathrm{pH} 8.0$ and at the time point of $178 \mathrm{~min}$, the aggregation of betalactoglobulin was suppressed $\sim 92.2 \%$ in the presence of a 1:1 (w:w) ratio of alpha-crystallin:beta-lactoglobulin. At $\mathrm{pH}$ values of 7.5, 7.0 and 6.5 at the same time point, Alpha-crystallin prevented the aggregation of betalactoglobulin by $\sim 76 \%, \sim 72 \%$ and $\sim 43 \%$ respectively.

SDS-PAGE electrophoresis of heated betalactoglobulin in the presence and absence of alphacrystallin at $\mathbf{p H ~ 7 . 0}$ and 8.0 values: Pellets and supernatants of the protein solutions (after heat induced aggregation experiments) at $\mathrm{pH}$ values of 8.0 and 7.0 were examined by SDS-PAGE for the distribution protein (Fig. 3A). Bands corresponding to $\sim 18 \mathrm{kDa}$ in 
Am. J. Biochem. \& Biotech., 4 (4): 317-324, 2008
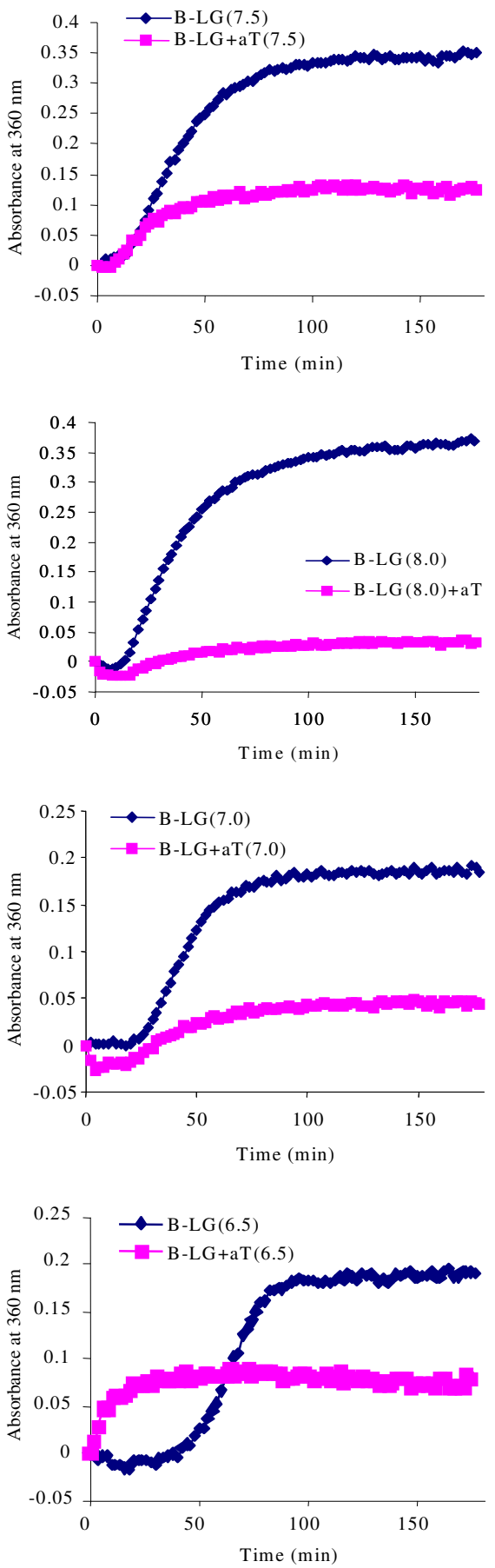

Fig. 2: Heat induced aggregation of beta-lactoglobulin at $5 \mathrm{mg} \mathrm{mL}^{-1}$ in the presence and absence of alpha-crystallin at different $\mathrm{pH}$ values. Protein was in total volume of $1 \mathrm{~mL}$ of $50 \mathrm{mM}$ phosphate buffer, $0.05 \% \mathrm{NaN}_{3}, 100 \mathrm{mM} \mathrm{NaCl}$ and $2.5 \mathrm{mM}$ EDTA and the incubation temperature was $70^{\circ} \mathrm{C}$

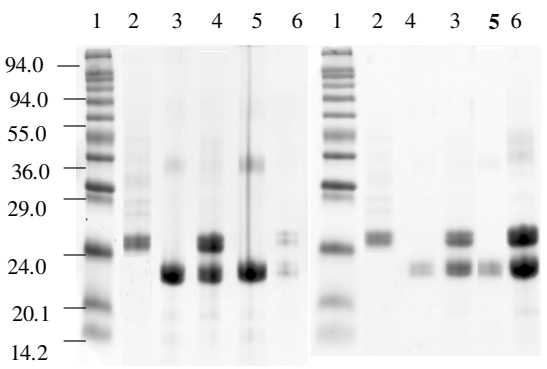

(A)

(B)

Fig. 3: SDS-PAGE gels showing the expression of (a) pellet and (b) supernatant of beta-lactoglobulin aggregation in the presence and absence of alpha-crystallin at $\mathrm{pH} 7.0$ and 8.0 values. For both gels Lane 1: Molecular weight markers, Lane (2) alpha-crystallin, Lane (3): betalactoglobulin at $\mathrm{pH}$ 7.0, Lane (4): betalactoglobulin and alpha-crystallin at $\mathrm{pH} 7.0$, Lane (5): beta-lactoglobulin at $\mathrm{pH}$ 8.0, Lane (6): beta-lactoglobulin and alpha-crystallin at $\mathrm{pH} 8.0$

mass were observed at $\mathrm{pH} 7.0$ and $\mathrm{pH} 8.0$ both in the pellet and supernatant. Two bands corresponding to $\sim 18$ and $20 \mathrm{kDa}$ in mass were also observed for betalactoglobulin and alpha-crystallin at $\mathrm{pH} 7.0$ and $\mathrm{pH} 8.0$ both in the pellet and supernatant. The strong bands shown in Lanes 3 and 5 in Fig. 3A show the precipitation of beta-lactoglobulin at $\mathrm{pH} 7.0$ and 8.0 values. In the supernatant the bands are very weak (Fig. 3B) indicating that beta-lactoglobulin mostly precipitated under these conditions when heated. Lanes 4 and 6 show the bands of beta-lactoglobulin and alphacrystallin at $\mathrm{pH} 7.0$ and $\mathrm{pH} \mathrm{8.0,} \mathrm{respectively.} \mathrm{At} \mathrm{pH} 7.0$, the intensity of the bands are stronger in the pellet compared to the supernatant. This means that most of protein precipitated and alpha-crystallin was not effective in preventing the precipitation of betalactoglobulin. In fact, alpha-crystallin and betalactoglobulin co precipitated indicating that alphacrystallin itself was destabilized under these conditions. At $\mathrm{pH} 8.0$, very faint bands were present in the pellet suggesting little precipitation while very strong bands in the supernatant are consistent with both proteins being present. This means that at $\mathrm{pH}$ 8.0, alphacrystallin was successful in forming a soluble complex with beta-lactoglobulin to prevent its aggregation and eventual precipitation. Thus, these data are consistent with alpha-crystallin being a more efficient chaperone at higher $\mathrm{pH}$ values as observed in the chaperone assay (Fig. 2). 
Am. J. Biochem. \& Biotech., 4 (4): 317-324, 2008
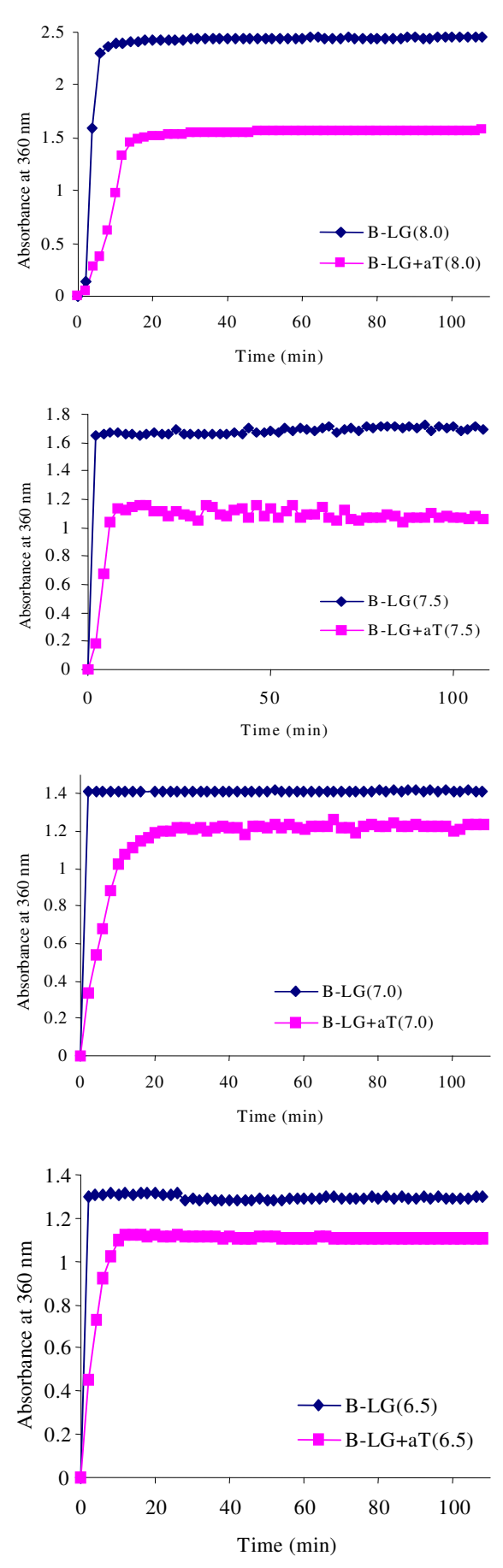

Fig. 4: Heat induced aggregation of reduced betalactoglobulin at $5 \mathrm{mg} \mathrm{mL}^{-1}$ in the presence and absence of alpha-crystallin and DTT at different $\mathrm{pH}$ values. Protein was in total volume of $1 \mathrm{~mL}$ of $50 \mathrm{mM}$ phosphate buffer, $0.05 \% \mathrm{NaN}_{3}, 100$ $\mathrm{mM} \mathrm{NaCl}, 2.5 \mathrm{mM}$ EDTA and $20 \mathrm{mM}$ DTT and the incubation temperature was $70^{\circ} \mathrm{C}$
Table 2: Summary of rate constants for the aggregation of reduced and heated beta-lactoglobulin at different $\mathrm{pH}$ values. The standard deviation obtained from Sigmaplot upon regeneration calculation

\begin{tabular}{ll}
\hline$\beta$-lactoglobulin & Rate constants $\times 10^{-1}\left(\mathrm{~min}^{-1}\right)$ \\
\hline $\mathrm{pH}(8.0)$ & $5.71 \pm 0.30$ \\
$\mathrm{pH}(7.5)$ & $1.50 \pm 1.5$ \\
$\mathrm{pH}(7.0)$ & $1.01 \pm 0.54$ \\
$\mathrm{pH}(6.5)$ & $1.47 \pm 1.1$ \\
\hline
\end{tabular}

Chaperone action of alpha-crystallin in preventing the aggregation of reduced and heated betalactoglobulin at different $\mathbf{p H}$ values: The chaperonelike action of alpha-crystallin in preventing aggregation of reduced and heated beta-lactoglobulin was examined at different $\mathrm{pH}$ values to compare the chaperone activity of alpha-crystallin with the non-reduced form of betalactoglobulin (Fig. 4). With increasing $\mathrm{pH}$, the aggregation of reduced beta-lactoglobulin increased even more than in the absence of DTT (compare Table 2 with Table 1). The efficiency of alpha-crystallin as a molecular chaperone decreased in the presence of DTT as demonstrated by its poorer protection of betalactoglobulin against aggregation. At $\mathrm{pH} 8.0$ and the time point of $100 \mathrm{~min}$, the aggregation of betalactoglobulin was suppressed by approximately $36 \%$ with a 1:1 ratio (w:w) of alpha-crystallin to betalactoglobulin. At pH values of 7.5, 7.0 and 6.5 at the same time point, alpha-crystallin prevented the aggregation of beta-lactoglobulin by approximately 34 , 15 and $14 \%$ respectively. These results show that DTT increased the rate of aggregation of heated betalactoglobulin and in this situation alpha-crystallin is a less efficient chaperone in preventing the aggregation of beta-lactoglobulin. Furthermore, the chaperone ability of alpha-crystallin increased with increasing $\mathrm{pH}$. This is consistent with other data showing that the chaperone ability of alpha-crystallin is less efficient for rapidly aggregating target protein ${ }^{[24,25]}$.

\section{DISCUSSION}

Beta-lactoglobulin aggregates via a combination of disulphide bond exchange (which leads to polymerization) and a nucleation-dependent mechanism due to hydrophobic association ${ }^{[26,27]}$. Mainly heatinduced aggregation of beta-lactoglobulin occurs through the formation of a dimer-monomer transition state of the protein. This transition state is characterized by a decrease in charge on the histidine residues of beta-lactoglobulin and an increased number of free thiol groups which in turn increases intermolecular thiol/disulfide linkage ${ }^{[23]}$. 
At $\mathrm{pH}$ values from 6.5-8.0, the aggregation and eventual precipitation of beta-lactoglobulin was investigated. The rate of aggregation of heat-stressed beta-lactoglobulin increased with increasing $\mathrm{pH}$, which is consistent with the $\mathrm{pH}$ dependence of disulphide bond cleavage ${ }^{[23,26]}$. Law et al. ${ }^{[23]}$ found that the rate of denaturation of beta-lactoglobulin was increased at higher $\mathrm{pH}$ values. A possible reason for this is that by increasing $\mathrm{pH}$, the net negative charge on the protein also increases, which in turn encourages intramolecular electrostatic repulsion. In order to counteract this increased charge, dissociation from the dimer to the monomer form of beta-lactoglobulin is favoured ${ }^{[23,28]}$. This also increases the activity of thiol groups and hence their tendency to form covalent bonds, which eventually leads to unfolding and aggregation of, heated beta-lactoglobulin ${ }^{[23,28]}$.

The effect of the molecular chaperone, alpha ${ }_{\mathrm{s}}$ casein, on preventing the aggregation of one of its natural targets, heat-stressed beta-lactoglobulin, has been previously demonstrated ${ }^{[29]}$, whereby $\mathrm{Alpha}_{\mathrm{s}}{ }^{-}$ casein effectively suppressed thermally induced aggregation of beta-lactoglobulin at $70^{\circ} \mathrm{C}$ and $\mathrm{pH} 7.0$ and this chaperone ability of alpha $\mathrm{s}_{\mathrm{s}}$-casein decreased with increasing $\mathrm{pH}$ which is the opposite in fact seen for alpha-crystallin. Devlin et al. ${ }^{[21]}$ observed that alpha-crystallin was not able to prevent the aggregation of serpin (AT), which aggregates via a polymerization mechanism rather than a nucleation-dependent mechanism. However, alpha-crystallin inhibited the aggregation of a serpin (ACT), which aggregated via a nucleation-dependent mechanism. Thus, would alphacrystallin inhibit beta-lactoglobulin aggregation and if so, would this decrease as the $\mathrm{pH}$ increased and via aggregation polymerization predominated? To answer these questions the chaperone action of alpha-crystallin was investigated in preventing the aggregation of heat stress beta-lactoglobulin at different $\mathrm{pH}$ values to determine its efficiency. It was found that at all $\mathrm{pH}$ values tested, alpha-crystallin prevented the aggregation of heat-stressed beta-lactoglobulin and this effect increased with increasing $\mathrm{pH}$. Incomplete suppression of protein aggregation and precipitation by alphacrystallin implies that the aggregation of betalactoglobulin occurs as a result of intermolecular disulphide bond polymerization. It has also been demonstrated that the chaperone action of Alphacrystallin increased with increasing $\mathrm{pH}^{[30]}$. At lower $\mathrm{pH}$ values, the aggregation of beta-lactoglobulin occurs more by hydrophobic (nucleation-dependent) mechanisms since disulphide bond cleavage is highly $\mathrm{pH}$ dependent (i.e., it is reduced at lower $\mathrm{pH}$ values $)^{[31,32]}$. Thus, it was proposed that even though alpha-crystallin's chaperone action is reduced at lower $\mathrm{pH}$ values, it should be able to prevent betalactoglobulin aggregation better at lower rather than at higher $\mathrm{pH}$ values. In fact, in this study it was found that despite increasing hydrophobic aggregation of betalactoglobulin at lower $\mathrm{pH}$, alpha-crystallin was a better chaperone at higher $\mathrm{pH}$. In agreement with this, SDSPAGE results confirmed the better chaperone action of alpha-crystallin at higher $\mathrm{pH}$. These results imply that the increase in polymerization of beta-lactoglobulin at higher $\mathrm{pH}$ and the inability of alpha-crystallin to suppress this is offset by the enhanced chaperone ability of alpha-crystallin to suppress nucleation-dependent aggregation at higher $\mathrm{pH}$.

Aggregation of beta-lactoglobulin occurs via both hydrophobic interactions and thiol/disulphide exchange reactions $^{[26,27]}$. Increased aggregation of heated betalactoglobulin in the presence of DTT showed that aggregation of beta-lactoglobulin occurs both via intramolecular and intermolecular disulphide bond formation (hydrophobic interactions and a nucleationdependent). Under these conditions beta-lactoglobulin aggregates much faster and alpha-crystallin is not a good chaperone $e^{[25]}$ to prevent its aggregation.

At room temperature and physiological $\mathrm{pH}$, betalactoglobulin exists as a dimer in which the monomers are noncovalently linked but dissociates into monomers upon heating ${ }^{[33]}$. beta-lactoglobulin undergoes heatinduced structural changes, which involve the exposure of buried hydrophobic groups and thiol groups ${ }^{[34]}$.

By contrast $^{[32]}$ provided evidence that polymerization of beta-lactoglobulin into a gel network does not occur via disulphide linkages. They explain that disulphide linkages occur initially during heating and the association of the soluble aggregates into a network occurs by non-covalent bonding which is a hydrophobic and/or hydrogen bond interaction. The aggregation of beta-lactoglobulin can be described using a kinetic model ${ }^{[14]}$. In this kinetic model, the aggregation of beta-lactoglobulin is described by analogy with a radical-addition polymerization and consists of three steps. In the initiation step, the betalactoglobulin dimer splits into monomers, a process in which reversible aggregation is followed by an irreversible step, which is the real initiation reaction. This real initiation is a first-order reaction and the conformation of beta-lactoglobulin changes in such way that the free thiol group becomes reactive. This reactive thiol group reacts via thiol/disulphide exchange. The polymerization process stops when two reactive intermediates react with each other, forming a polymer without a reactive thiol group ${ }^{[14]}$. According to these data, at all $\mathrm{pH}$ values tested, aggregation of beta- 
lactoglobulin occurs via both intermolecular exchange and hydrophobic interaction as showed in this study by the increasing aggregation of beta-lactoglobulin in the presence of DTT. It appears that increasing chaperone action of alpha-crystallin at higher $\mathrm{pH}$ rather than the hydrophobic aggregation by beta-lactoglobulin at lower $\mathrm{pH}$ is the predominant force for the chaperone action of alpha-crystallin. One explanation is that by increasing $\mathrm{pH}$, the chaperone action of alpha-crystallin increases, which prevents both hydrophobic aggregation and noncovalent association of beta-lactoglobulin into a gel network. Another possibility could be that alphacrystallin reverses the dimer-dissociation of heatinduced aggregation of beta-lactoglobulin, which is a necessary step in the aggregation process of betalactoglobulin ${ }^{[13]}$.

\section{CONCLUSION}

This study reveals that upon heating, betalactoglobulin aggregation increased with increasing $\mathrm{pH}$. As shown by light scattering profiles, the presence of DTT led to more rapid aggregation and precipitation of beta-lactoglobulin. Increasing aggregation of betalactoglobulin occurred in the presence of DTT implying that the aggregation of beta-lactoglobulin occurs via both intra and intermolecular disulphide bond formation. Alpha-crystallin prevented the aggregation of heat-stressed beta-lactoglobulin and was a more efficient chaperone at higher $\mathrm{pH}$ values. In the presence of DTT, however, alpha-crystallin was a less efficient chaperone due to faster aggregation of heated and reduced beta-lactoglobulin.

\section{ACKNOWLEDGEMENT}

I wish to acknowledge the Editor Dr M.S. Ahmad, two anonymous referees, Dr Agata Rekas and Dr Teresa Treweek for their useful comments on a previous draft of this study. The usual caveat applies.

\section{REFERENCES}

1. Puyol, P., M.D. Perez, J.M. Peiro and M. Calvo, 1994. Effect of binding of retinol and palmitic acid to bovine beta-lactoglobulin on its resistance to thermal denaturation. J. Dairy. Sci., 77: 1494-1502. http://jds.fass.org/cgi/content/abstract/77/6/1494.

2. Manderson, G.A., M.J. Hardman and L.K. Creamer, 1998. Effect of heat treatment on the conformation and aggregation of beta-lactoglobulin A, B and C: J. Agric. Food Chem., 46: 5052-5061. http://cat.inist.fr/?aModele $=$ afficheN\&cpsidt $=1656$ 578 .
3. Verheul, M., S.P. Roefs and K.G. de. Kruif, 1998. Kinetics of Heat-induced aggregation of betalactoglobulin: J. Agric. Food Chem., 46: 896-903. http://pubs.acs.org/cgi-bin/abstract.cgi/jafcau/ 1998/46/i03/abs/jf970751t.html.

4. Croguennec, T., S. Bouhallab, D. Molle, B.T. O'Kennedy and R. Mehra, 2003. Stable monomeric intermediate with exposed Cys-119 is formed during heat denaturation of betalactoglobulin. Biochem. Biophys. Res. Commun., 301: 465-471. http://www.ncbi.nlm.nih.gov/ pubmed/12565885.

5. Livney, Y.D., E. Verespej and D.G. Dalgleish, 2003. Steric effects governing disulfide bond interchange during thermal aggregation in solutions of beta-lactoglobulin B and alpha-lactalbumin: J. Agric. Food Chem., 51: 8098-8106. http://pubs.acs.org/cgi-bin/abstract.cgi/jafcau/2003/ 51/i27/abs/jf034582q.html.

6. Manderson, G.A., L.K. Creamer and M.J. Hardman, 1999. Effect of heat treatment on the circular dichroism spectra of bovine betalactoglobulin A, B and C. J. Agric. Food Chem., 47: 4557-4567. http://pubs.acs.org/cgibin/abstract.cgi/jafcau/1999/47/i11/abs/jf981291m. html.

7. Creamer, L.K., A. Bienvenue, H. Nilsson, M. Paulsson, M.V. Wanroij, E.K. Lowe, A.G. Skelte, M.J. Boland and R. Jimenez-Flores, 2004. Heat-induced redistribution of disulfide bonds in milk proteins. 1 . bovine betalactoglobulin. J. Agric. Food Chem., 52: 7660-7668. http://works.bepress.com/rjimenez/ 46/.

8. Livney, Y.D. and D.G. Dalgleish, 2004. Specificity of disulfide bond formation during thermal aggregation in solutions of beta-lactoglobulin B and K-casein A. J. Agric. Food. Chem., 52: 5527-5532. http://lib.bioinfo.pl/auth:Livney, YD.

9. Hoffman, M.A., G. Sala, C. Olieman and C.G. de Kruif, 1997. Molecular mass distributions of heatinduced beta-lactoglobulin. J. Agric. Food Chem., 45:

2949-2957.

http://www.scopus.com/scopus/record/display.url? view=basic \&eid=2-s2.0 0001266819\&origin=resultslist\&sort $=$ plf -

$\mathrm{f} \& \mathrm{src}=\mathrm{s} \& \mathrm{st} 1=$ Hoffmann+M.A.\&st $2=\& \mathrm{sid}=\mathrm{KfD} 9 \mathrm{v}$ GAipXdr5cM_vcXBmVj\%3a50\&sot=b\&sdt=b\&sl $=26 \& \mathrm{~s}=$ AUTHOR-

NAME\%28Hoffmann+M.A.\%29\&relpos $=17$

10. Fox, P.F. and P.L.H. McSweeney, 1998. Dairy Chemistry and Biochemistry. Blackie Academic and Professional: London, ISBN: 0-412-72000-0. 
11. Iammeti, S., S. Cairoli, B. de Gregory and F. Bonomi, 1995. Modifications of high-order structures upon heating of beta-lactoglobulin: Dependence on protein concentration. J. Agric. Food Chem., 43: 53-58. http://pubs.acs.org/cgibin/abstract.cgi/jafcau/1995/43/i01/f-pdf/f_ jf00049a011.pdf?sessid=600613

12. Galani, D. and R.K.O. Apenten, 1999. Heatinduced denaturation and aggregation of betalactoglobulin: Kinetics of formation of hydrophobic and disulphide-linked aggregation. Int. J. Food Sci. Tech., 34: 467-476. http://www3.interscience.wiley.com/journal/11909 5028/abstract

13. Cairoli, S., S. Iametti and F. Bonomi, 1994. Reversible and irreversible modifications of betalactoglobulin upon exposure to heat. J. Protein Chem., 13: 347-354. http://www.ncbi.nlm.nih.gov/ pubmed/7945798.

14. Roefs, S.P.F.M. and C.G. de Kruif, 1994. A model for the denaturation and aggregation of betalactoglobulin: Eur. J. Biochem., 226: 883-889. http://www3.interscience.wiley.com/journal/11926 2936/abstract.

15. Raman, B., T. Ramakrishna and M.C. Rao, 1995. Temperature dependent chaperone-like activity of alpha-crystallin: FEBS Lett., 365: 133-136. Doi: 10.1016/0014-5793(95)00440-K.

16. Datta, S.A. and C.M. Rao, 1999. Differential temprature-dependent chaperone-like activity of alphaA- and alphaB-crystallin homoaggregates. J. Biol.Chem., 274: 34773-34778. http://www.jbc. org/cgi/content/abstract/274/49/34773.

17. Ingolia, T. and E. Craig, 1982. Four small Drosophila heat shock proteins are related to each other and to mammalian alpha-crystallin. Proc. Natl. Acad. Sci. USA., 79: 2360-2364. http://www. pubmedcentral.nih.gov/articlerender.fcgi?artid=346 193.

18. Horwitz, J., 1992. Alpha-Crystallin can function as a molecular chaperone. Proc. Natl. Acad. Sci. USA., 89: 10449-10453. http://www. pubmedcentral.nih.gov/articlerender.fcgi?rendertyp $\mathrm{e}=$ abstract\&artid=50356.

19. Lindner, R.A., T.M. Treweek and J.A. Carver, 2001. The molecular chaperone alpha-crystallin is in kinetic competition with aggregation to stabilize a monomeric molten-globule form of alphalactalbumin.Biochem. J., 354: 79-87. http://www. biochemj.org/bj/354/0079/bj3540079.htm.
20. Carver, J.A, R.A. Lindner, C. Lyon, D. Canet, H. Hernandez, C.M. Dobson and C. Redfield, 2002. The interaction of the molecular chaperone alpha-crystallin with unfolding alpha-lactalbumin: A structural and kinetic spectroscopic study. J. Mol. Biol., 318: 815-827. Doi: 10.1016/S00222836(02)00144-4.

21. Devlin, G.L., J.A. Carver and S.P. Bottomley, 2003. The selective inhibition of serpin aggregation by the molecular chaperone, alpha-crystallin indicates a nucleation-dependent specificity. J. Biol.Chem., 278: 48644-48650. http://www.jbc. org/cgi/content/abstract/278/49/48644.

22. Slingsby, C. and O.A. Bateman, 1990. Rapid separation of bovine beta-crystallin subunits BetaB1, BetaB2, BetaB3, BetaA4. Exp. Eye Res., 51: 21-26. http://www.ncbi.nlm.nih.gov/pubmed/ 2373177.

23. Law, A.J. and J. Leaver, 2000. Effect of pH on the thermal denaturation of whey proteins in milk. J. Agric. Food Chem., 48: 672-679. Doi: 10.1021/jf981302b S0021-8561(98)01302-8.

24. Lindner, R.A., A. Kapur, M. Mariani, S.J. Titmuss and J.A. Carver, 1998. Structural alterations of alpha-crystallin during its chaperone action. Eur. J. Biochem., 258: 170-183. Doi: 10.1046/j.14321327.1998.2580170.x.

25. Ghahghaei, A., A. Rekas., W.E. Price., G.A. Carver, 2007. The effect of dextran on subunit exchange of the molecular chaperone alphaAcrystallin. Biochem. Biophys. Acta., 1774: 102-111. Doi: 10.1016/J.Bbapap.2006.10.002.

26. Hoffman, M.A. and P.J.J.M. van Mil, 1997. Heatinduced aggregation of beta-lactoglobulin: Role of thiol group and disulphide bonds. J. Agric. Food Chem., 45: 2942-2948. http://library.wur.nl/wda/ dissertations/dis3396.pdf\#page $=21$.

27. Croguennec, T., D. Molle, R. Mehra and S. Bouhallab, 2004. Spectroscopic characterization of heat-induced nonnative beta-lactoglobulin monomers. Prot. Sci., 13: 1340-1346. Doi: 10.1110/ps.03513204

28. Qi, X.L., S. Brownlow, C. Holt and P. Sellers, 1995. Thermal denaturation of beta-lactoglobulin: Effect of protein concentration at $\mathrm{pH} 6.75$ and 8.05. Biochim. Biophys. Acta., 1248: 43-49. Doi: 10.1016/0167-4838(94)00225-6. 
29. Morgan, P.E., T.M. Treweek, R.A. Lindner, W.E. Price and J.A. Carver, 2005. Casein proteins as molecular chaperones. J. Agric. Food Chem., 53: 2670-2683. Doi: 10.1021/jf048329h S00218561(04)08329-3.

30. Hoffman, M.A. and P.J.J. M. van Mil, 1999. Heatinduced aggregation of beta-lactoglobulin as a function of pH. J. Agr. Food. Chem. 47, 1898-1905. http://www.scopus.com/scopus/record/display.url? view=basic \&eid=2-s2.0-

$0000008542 \&$ origin $=$ resultslist $\&$ sort $=$ plf$\mathrm{f} \& \mathrm{src}=\mathrm{s} \& \mathrm{st} 1=$ Hoffmann+M.A.\&st $2=\&$ sid=KfD9vGAip Xdr5cM_vcXBmVj\%3a50\&sot=b\&sdt=b\&sl=26\&s=AU THOR-NAME\%28Hoffmann+M.A.\%29\&relpos $=18$

31. Prabakaran, S. and S. Damodaran, 1997. Thermal unfolding of beta-lactoglobulin: Characterization of initial unfolding events responsible for heatinduced aggregation. J. Agric. Food Chem., 45: 4303-4308. http://pubs.acs.org/cgi-bin/abstract.cgi/ jafcau/1997/45/i11/abs/jf970269a.html.
32. Otte, J., M. Zakora and K.B. Qvist, 2000. Involvement of disulphide bonds in bovine betalactoglobulin B gels set thermally at various $\mathrm{pH}$. J. Food. $\quad$ Sci., 65: 384-389. http://www.scopus.com/scopus/record/display.url? view=basic \&eid=2-s2.0-0034089645\&origin

33. Verheul, M., J.S. Pedersen, S.P. Roefs and K.G. de Kruif, 1999. Association behavior of native betalactoglobulin.Biopolymers, 49: 11-20. http://grande.nal.usda.gov/ibids/index.php?mode2= detail\&origin=ibids_references\&therow $=644525$.

34. Ptitsyn, O.B., 1995. Molten globule and protein folding. Adv. Protein. Chem., 47: 83-229. http://cat.inist.fr/?aModele $=$ afficheN\&cpsidt $=1117$ 5412. 